\title{
Mechanisms Underlying the Antiproliferative and Prodifferentiative Effects of Psoralen on Adult Neural Stem Cells via DNA Microarray
}

\author{
You Ning, ${ }^{1}$ Jian-Hua Huang, ${ }^{1}$ Shi-Jin Xia, ${ }^{2}$ Qin Bian, ${ }^{1}$ Yang Chen, ${ }^{1}$ Xin-Min Zhang, \\ Jing-Cheng Dong, ${ }^{1}$ and Zi-Yin Shen ${ }^{1}$ \\ ${ }^{1}$ Institute of Integrated Traditional Chinese Medicine and Western Medicine, Huashan Hospital, Fudan University, \\ Shanghai 200031, China \\ ${ }^{2}$ Shanghai Institute of Geriatrics, Huadong Hospital, Fudan University, Shanghai 200031, China \\ Correspondence should be addressed to Zi-Yin Shen; ziyinshen@126.com
}

Received 21 March 2013; Accepted 28 April 2013

Academic Editor: Yong Qing Yang

Copyright (c) 2013 You Ning et al. This is an open access article distributed under the Creative Commons Attribution License, which permits unrestricted use, distribution, and reproduction in any medium, provided the original work is properly cited.

\begin{abstract}
Adult neural stem cells (NSCs) persist throughout life to replace mature cells that are lost during turnover, disease, or injury. The investigation of NSC creates novel treatments for central nervous system (CNS) injuries and neurodegenerative disorders. The plasticity and reparative potential of NSC are regulated by different factors, which are critical for neurological regenerative medicine research. We investigated the effects of Psoralen, which is the mature fruit of Psoralea corylifolia L., on NSC behaviors and the underlying mechanisms. The self-renewal and proliferation of NSC were examined. We detected neuron- and/or astrocytespecific markers using immunofluorescence and Western blotting, which could evaluate NSC differentiation. Psoralen treatment significantly inhibited neurosphere formation in a dose-dependent manner. Psoralen treatment increased the expression of the astrocyte-specific marker but decreased neuron-specific marker expression. These results suggested that Psoralen was a differentiation inducer in astrocyte. Differential gene expression following Psoralen treatment was screened using DNA microarray and confirmed by quantitative real-time PCR. Our microarray study demonstrated that Psoralen could effectively regulate the specific gene expression profile of NSC. The genes involved in the classification of cellular differentiation, proliferation, and metabolism, the transcription factors belonging to Ets family, and the hedgehog pathway may be closely related to the regulation.
\end{abstract}

\section{Introduction}

Adult neural stem cells (NSCs) in the adult nervous system serve as a common source of all neural cells, including neurons, astrocytes, and oligodendrocytes [1]. NSCs persist throughout life in the subgranular zone (SGZ) and the subventricular zone (SVZ) [2] to replace mature cells that are lost during turnover, disease, or injury. NSCs remain relatively quiet under normal circumstances [3]. However, various stimuli, such as blood anoxia, trauma, and oxidative stress, initiate the proliferation and differentiation of NSC [4]. NSCs continually self-renew and expand the pool of undifferentiated cells during early stages. These actively proliferating NSC create neurons and subsequently differentiate into astrocytes and oligodendrocytes. Neurons are the functional components of the nervous system, and they are responsible for information processing and transmission. In contrast, astrocytes and oligodendrocytes are collectively known as glia and play supporting roles that are essential for the proper functioning of the nervous system. Astrocytes have become the focus of brain function research in recent years. Mouse brain astrocytes modulate the excitation of inhibitory neurons and inhibit the general activity of surrounding neurons to prevent the overexcitation of neurons in the nerve ring [5]. Neurons cannot produce an enhanced response without the help of astrocytes [6]. This long-term neuronal reaction is the basis of learning and memory. Astrocytes may aid neurons in the production of this enhanced response for a few hours or several days. Astrocytes may play an important role in brain functional activities.

The plasticity and reparative potential of NSC is regulated by various factors, such as neurotransmitters, growth factors, 
and other extrinsic factors [7]. Therefore, the factors that control the balance between NSC proliferation and differentiation are critical for neurological regenerative medicine research.

Recent evidence suggests that Chinese traditional medicines protect neural cells, improve the ability to resist the damage, and induce NSC proliferation and differentiation [8]. Notably, some herbs may be involved in the maintenance of NSC, but others induce neurogenesis or astrogenesis. The literature [9] suggests that astragaloside as the main active components in astragalus (Huang-Qi in Chinese) significantly promotes the proliferation of NSCs in vitro. Another evidence [10] has established that the combination of BDNF and salidroside can promote the NSCs in the epileptic brain tissues that differentiate into GABA neurons. Therefore, the use of Chinese medicine and its effective ingredients in NSC research generates a novel direction in nerve regeneration research and demonstrates great potential for the curing of diseases of the central nervous system.

Psoralens are the linear isomers of the furocoumarin family. Psoralen is extracted from the mature fruit of Psoralea corylifolia L. (Bu-Gu-Zhi in Chinese) and exhibit photosensitizing effects and various biological activities. Psoralen is commonly used in combination with long wavelength ultraviolet light for the treatment of a variety of skin diseases, such as psoriasis, vitiligo, cutaneous T-cell lymphoma, pemphigus vulgaris, systemic sclerosis, and systemic lupus erythematosus [11-15]. Varying degrees of remission of these diseases occur after Psoralen treatment. The ability of Psoralen to modulate the proliferation and differentiation of cultured cells in vitro, including epidermal cells [16], vascular smooth muscle cells [17], bladder carcinoma cells [18], mucoepidermoid carcinoma cells [19], mammary cancer cells [20], and osteoblasts [21], has been investigated. Psoralen induces transformation from the G1 phase to the $S$ phase or the G2 phase in osteoblasts, which suggests that these compounds effectively regulate progenitor and stem cells.

A series of experiments were performed to examine the role of Psoralen on the proliferation, multidirectional differentiation of NSC. Microarray libraries were generated from the Psoralen-treated NSC to systematically analyze the transcript profile of Psoralen-treated NSC and gain insight into the underlying molecular mechanisms.

\section{Materials and Methods}

2.1. Animals. Pregnant Kunming female mice were maintained in the animal facility of the Public Health Center of Fudan University. All procedures were approved by the Animal Care and Use Committee of Fudan University in accordance with the guidelines for animal use of the National Institutes of Health.

2.2. NSC Preparation and Culture. Neurosphere culture was performed as described previously [22] with some modifications. Mouse embryos at embryonic day 14 (E14) were collected from timed-pregnant Kunming mice and placed in D-PBS (Invitrogen, CA, USA). The forebrain neuroepithelium was removed from the embryos under a dissection microscope. The resultant tissue was dissociated by mechanical dissociation into a single-cell suspension using a smallbore, fire-polished Pasteur pipette. The cells were filtered through a sterile nylon mesh and washed twice with a DMEM/F12 medium (Invitrogen, CA, USA) containing 100 units $/ \mathrm{mL}$ penicillin and $100 \mu \mathrm{g} / \mathrm{mL}$ streptomycin. The number of viable cells was determined by trypan blue staining. Neurosphere culture was initiated by seeding the cells at a density of $1 \times 10^{5}$ to $2 \times 10^{5}$ viable cells $/ \mathrm{mL}$ in the basal medium supplemented with $20 \mathrm{ng} / \mathrm{mL}$ human recombinant fibroblast growth factor-2 (hrFGF2, Invitrogen, CA, USA), $20 \mathrm{ng} / \mathrm{mL}$ human recombinant endothelial growth factor (hrEGF, Invitrogen, CA, USA), and Stempro NSC supplement (Invitrogen, CA, USA). The surface of the culture dishes was coated with Poly-D lysine (PDL) $(10 \mathrm{mg} / \mathrm{mL}$, Millipore, USA) to prevent cell attachment.

2.3. Neurosphere Formation Assay. Cells were plated under clonal conditions at 5 cells $/ \mu \mathrm{L}$ in 96 -well plate $(0.1 \mathrm{~mL} /$ well $)$ in serum-free DMEM/F12 medium containing $20 \mathrm{ng} / \mathrm{mL}$ hrFGF-2 (Invitrogen, CA, USA), Stempro NSC supplement (Invitrogen, CA, USA), 100 units/mL penicillin and $100 \mu \mathrm{g} / \mathrm{mL}$ streptomycin. The next day, various concentrations (10 nM, $50 \mathrm{nM}$, and $100 \mathrm{nM}$ ) of Psoralen (Yousi Biotechnology, Shanghai, China; purity above 99\% HPLC) were added to each well. The total number of spheres that formed in each well was quantified after $8 \mathrm{~d}$. Only colonies $>40 \mu \mathrm{m}$ in diameter were counted as neurospheres. Neurosphere size was determined by measuring the diameters of individual neurospheres under light microscopy, and it is expressed as a volume (assuming a spherical shape). The consecutive second, third, or fourth passages were used to determine neurosphere formation.

2.4. Cell Proliferation Assay. Cell proliferation was based on the incorporation of EdU and its subsequent detection by a fluorescent azide through a $\mathrm{Cu}(\mathrm{I})$-catalyzed $[3+2]$ cycloaddition reaction ("click" chemistry) as described previously [23]. In brief, single NSCs were grown in 96-well plates in DMEM/F12 medium containing $20 \mathrm{ng} / \mathrm{mL}$ hrFGF-2 and hrEGF (Invitrogen, CA, USA), Stempro NSC supplement (Invitrogen, CA, USA), 100 units/mL penicillin, and $100 \mu \mathrm{g} / \mathrm{mL}$ streptomycin. EdU was added to the culture media in a final concentration of $10 \mu \mathrm{M}$ for $3 \mathrm{~h}$. Cells were fixed in formaldehyde and penetrated with $0.5 \%$ Triton X-100. The cells were stained during a $30 \mathrm{~min}$ incubation with $100 \mathrm{mM}$ Tris, $0.5 \mathrm{mM} \mathrm{CuSO}_{4}, 10 \mu \mathrm{M}$ Alexa 594-azide, and $50 \mathrm{mM}$ ascorbic acid. Cells were counterstained with $4^{\prime}-6$ diamidino-2-phenylindole (DAPI). The cells were washed and imaged using fluorescence microscopy.

2.5. Differentiation Assay. Single NSCs were plated at a density of 5000 cells/well in $10 \mu \mathrm{g} / \mathrm{mL}$ PDL-coated 96-well culture dishes (Corning, NY, USA) and incubated for $3 \mathrm{~d}$ in a differentiation medium of DMEM/F12 containing 1\% fetal bovine serum (Invitrogen, CA, USA), Stempro NSC supplement (Invitrogen, CA, USA), 100 units/mL penicillin, and 
$100 \mu \mathrm{g} / \mathrm{mL}$ streptomycin. The cells were harvested $3 \mathrm{~d}$ later for Western blot and immunocytochemical analyses.

2.6. Western Blot Analysis. Cells cultured using the differentiation protocol were harvested and lysed in a buffer containing $50 \mathrm{mM}$ HEPES-NaOH (pH 7.5), $100 \mathrm{mM} \mathrm{KCl,} \mathrm{1 \%} \mathrm{Triton}$ $\mathrm{X}-100,1 \%$ sodium deoxycholate, $0.1 \%$ sodium dodecyl sulfate, $1 \mathrm{mM}$ EGTA, $1 \mathrm{mM}$ dithiothreitol, $1 \mathrm{mM}$ phenylmethylsulfonyl fluoride, $0.5 \%$ protease inhibitor cocktail (SigmaAldrich, MO, USA), $1 \mathrm{mM} \mathrm{Na} \mathrm{VO}_{4}, 10 \mathrm{mM} \mathrm{NaF}$, and $20 \mathrm{mM}$ $\beta$-glycerophosphate. The resultant extracts were centrifuged at $14,000 \mathrm{~g}$ for $15 \mathrm{~min}$ at $4^{\circ} \mathrm{C}$ to obtain clear cell lysates. Protein concentrations were determined using the Biotime protein assay kit (Beyotime, Shanghai, China) with BSA as a standard. Equal amounts of $35 \mu \mathrm{g}$ of proteins were loaded on a sodium dodecyl sulfate polyacrylamide gel and separated by electrophoresis. Separated proteins were transferred to nitrocellulose membranes (Amersham Biosciences, USA). The membranes were blocked with $5 \%(\mathrm{w} / \mathrm{v})$ skim milk in phosphatebuffered saline containing $0.1 \%$ Tween 20 and blotted with antibodies for glial fibrillary acidic protein (GFAP) (1:500; Chemicon, USA) and $\beta$-tubulin III (TuJ1) $(1: 200$, Chemicon, USA) followed by incubation with appropriate sets of secondary HRP-conjugated goat anti-mouse or rabbit antibodies (1:5000; Jackson ImmunoResearch, USA). Immunoreactive bands were visualized with ECL reagents (Biyotime, Shanghai, China).

2.7. Immunocytochemistry. The cells cultured using the differentiation protocol were fixed for $20 \mathrm{~min}$ in $4 \%$ paraformaldehyde, blocked in $1 \%$ BSA and $0.1 \%$ Triton X-100, washed with PBS, incubated for $30 \mathrm{~min}$ with $0.3 \% \mathrm{H}_{2} \mathrm{O}_{2}$ to inhibit endogenous peroxidases, and blocked for $1 \mathrm{~h}$ using $3 \%$ BSA in $\mathrm{PBS} / 0.1 \%$ Triton $\mathrm{X}-100$. The following primary antibodies were incubated for 2 hours at room temperature: monoclonal rabbit anti-GFAP (1:500; Chemicon, USA), mouse anti-TuJ1 (diluted 1:200; Chemicon, USA), and rabbit antinestin $(1: 1000$, Chemicon, USA). Secondary Alexaconjugated $594 \mathrm{~F}(\mathrm{ab})^{\prime} 2$ goat anti-rabbit antibody and 488 Alexa-conjugated goat anti-mouse $\operatorname{IgG}(\mathrm{H}+\mathrm{L})(1: 1000$; Invitrogen, USA) were added for $1.5 \mathrm{~h}$ in PBS in $1 \%$ BSA and $0.1 \%$ Triton X-100. The cells were counterstained with DAPI. The number of immunoreactive cells in each well was quantified using fluorescent microscopy.

2.8. Microarray and Data Analysis. The cells cultured using the differentiation protocol for 3 days were harvested and lysed in TRIzol Reagent (Invitrogen, USA). Total RNA was isolated using the Qiagen RNeasy kit (Qiagen) in accordance with the manufacturer's protocol. The isolated RNA was subject to a quality control test. RNA from each sample was used for cDNA synthesis followed by the labeling of the cDNA with Cy3. The labeled cDNA samples were submitted to NimbleGen and hybridized to Mouse Gene Expression 12x135K Arrays (Roche NimbleGen, 05543797001) that represent 44,170 mouse genes. The single-color NimbleGen arrays were scanned using a GenePix $4000 \mathrm{~B}$ microarray scanner. The data were extracted from the scanned images using NimbleScan v2.5 Software. Expression data were normalized through quantile normalization, and the Robust Multichip Average (RMA) algorithm was included in the NimbleScan software. The Probe level (*_norm_RMA.pair) files and Gene level (*_RMA.calls) files were generated after normalization. All gene level files were imported into Agilent GeneSpring GX software (version 11.5.1) for further analysis.

2.9. Quantitative Real-Time PCR. Total RNA from cells was extracted using TRIzol reagent (Invitrogen, USA). One microgram of total RNA was reverse transcribed using the Advantage RT-for-PCR kit (Qiagen, Valencia, CA). Freshly transcribed cDNA was used for quantitative real-time PCR using SYBR Green (Bio-Bad, Hercules, CA). The primers for each gene were designed using the online tool, Primer3 (http://frodo.wi.mit.edu/), and the sequences are listed in supplementary Table 1. PCR was performed using a RotorGene real-time DNA amplification system (Corbett Research, Sydney, Australia) as described in our previous study [24].

2.10. Bioinformatic Analysis. Differentially expressed genes $(P<0.05)$ between the control and Psoralen-treated groups were functionally annotated via the functional annotation tool, Database for Annotation, Visualization, and Integrated Discovery (DAVID) (http://david.abcc.ncifcrf.gov/), which was developed within the Gene Ontology Consortium [25]. The KEGG pathways of the differentially expressed genes between the control and Psoralen-treated groups were also matched using the DAVID functional annotation tool.

The key regulatory processes of the Psoralen effect were analyzed using the Gene Ontology (GO) Tree Machine (http://bioinfo.vanderbilt.edu/webgestalt/) [26]. The directed acyclic graph (DAG) was generated automatically by the GO Tree Machine for the input gene sets, which was created to identify the most important GO categories and suggest their potential biological importance.

Transcription factors are of great significance for cellular differentiation and proliferation. The online tool, oPOSSUM (http://www.cisreg.ca/oPOSSUM/), was used for the analysis of transcription factor binding sites of differentially expressed genes [27].

2.11. Statistical Analysis. All data were expressed as the means \pm SD. The statistical significance was calculated using Oneway ANOVA (analysis of variance) followed by the least significant difference (LSD) test for post hoc analysis. The significance level was defined as $P<0.05$. The number of replicated experiments is indicated in the results section or the figure legends.

\section{Results}

3.1. Psoralen Inhibited Neurosphere Formation. Neurosphere formation demonstrates the self-renewal ability of NSC when single NSC are plated at a very low cell density. NSC formed neurospheres of various sizes in our growth culturing conditions with diameters ranging from $20 \mu \mathrm{m}$ to greater than $100 \mu \mathrm{m}$ (Figure 1(a)). These neurospheres exhibited positive 


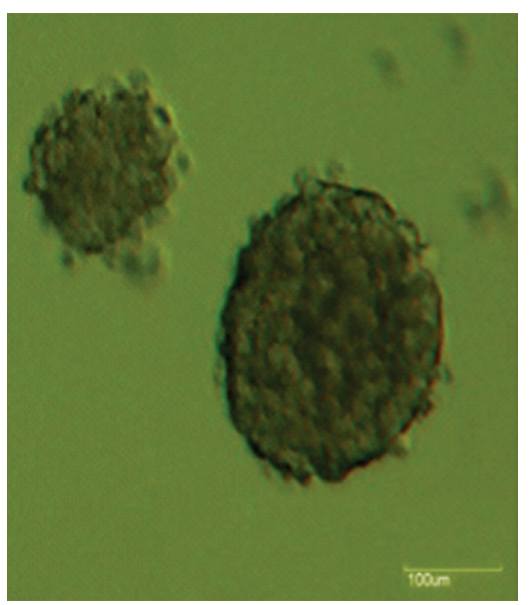

(a)

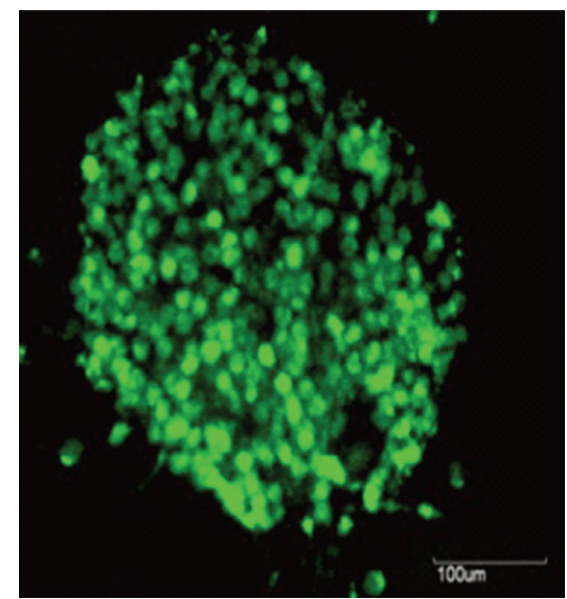

(b)

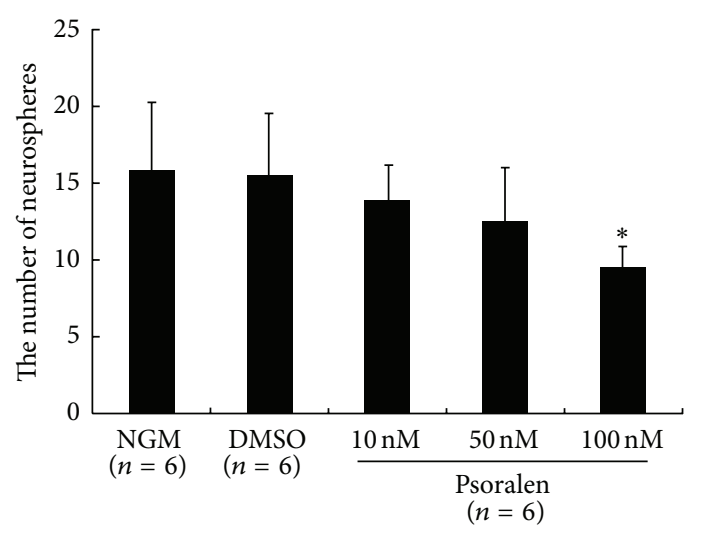

(c) the number of neurospheres

FIGURE 1: Effects of Psoralen on neurosphere formation of neural stem cells in vitro. Single NSCs at a density of 500 cells/well were cultured in normal growth medium (NGM) containing DMEM/F12 supplemented with hrFGF for 7 days to form various size of neurospheres (a). The neurospheres expressed NSC marker nestin (b). Single NSCs were exposed to NGM, DMSO (0.1\%), and 10, 50, $100 \mathrm{nM}$ Psoralen dissolved in DMSO (0.1\%), respectively. Psoralen caused a significant decrease in frequency of neurosphere formation (c). Scale bars: $100 \mu \mathrm{m}$. Results were expressed as mean \pm S.D. of six independent experiments. ${ }^{*} P<0.05$ versus NGM.

nestin staining (NSC marker), which suggests the presence of NSC and/or neural progenitor cells (Figure 1(b)). We calculated the frequency of neurosphere formation in the presence or absence of Psoralen. The control group formed $15.75 \pm 4.43(n=6)$ neurospheres from the initially seeded 500 hundred cells (frequency of approximately 3.15\%). The solvent (DMSO) did not alter the frequency of neurosphere formation $(15.5 \pm 3.99, n=6)$. The neurosphere frequencies for the low $(10 \mathrm{nM})$, middle $(50 \mathrm{nM})$, and high $(100 \mathrm{nM})$ concentrations of Psoralen were 13.91 $\pm 2.17,12.56 \pm 3.41,9.43 \pm$ $1.53(n=6)$, respectively. The high Psoralen concentration $(100 \mathrm{nM})$ significantly decreased the neurosphere formation of NSC compared to control $(P<0.05)$ (Figure $1(\mathrm{c}))$.

3.2. Psoralen Inhibited NSC Proliferation. The decrease in neurosphere formation may have been due to a compromised cell proliferation of NSC. Therefore, we investigated NSC proliferation in the presence of Psoralen using EdU incorporation, which identifies cells in the $S$ phase of the cell cycle.
The ratio of EdU-positive cells to total cells was $18.8 \pm 3.2 \%$ ( $n=4)$ in the control group. The incorporation of EdU into NSC decreased significantly in the presence of $100 \mathrm{nM}$ Psoralen (12.6 $\pm 0.8 \%, n=4 ; P<0.05$ versus control) (Figures 2(a), 2(b), and 2(c)).

3.3. Psoralen Induced the Differentiation of NSC to Astrocytes. Single cells were cultured in a monolayer on PDL-coated dishes in serum without growth factors for $48 \mathrm{~h}$. Immunochemistry revealed that $43.93 \pm 6.21 \%(n=4)$ of cells in the control group were GFAP-positive (Figure 3(a)) and $18.45 \pm 4.6 \%(n=4)$ of cells were TuJ1-positive (Figure 3(b)), which suggests multi-potential NSC. The percentage of TuJ1positive cells did not change after Psoralen treatment $(P>$ 0.05 versus control) (Figure 3(c)), but the percentage of GFAP-positive cells significantly increased to $54.32 \pm 6.33 \%$ ( $n=4 ; P<0.05$ versus control) (Figure 3(d)). Western blotting analyses of total cell lysates in the Psoralen-treated or untreated cells revealed an increase in GFAP expression. 


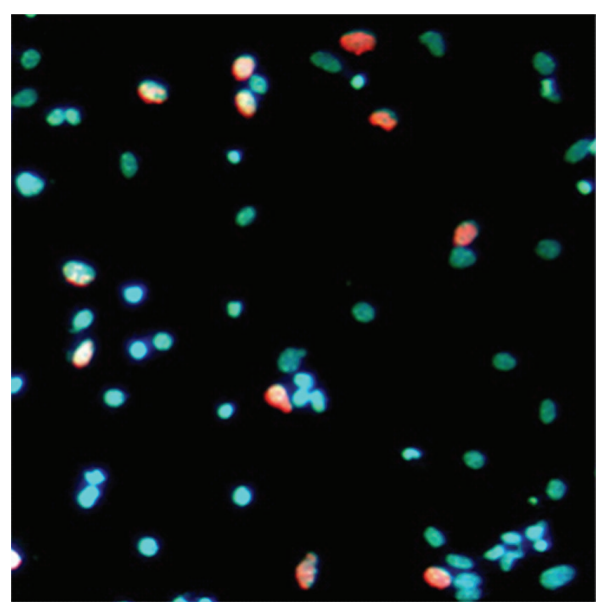

(a)

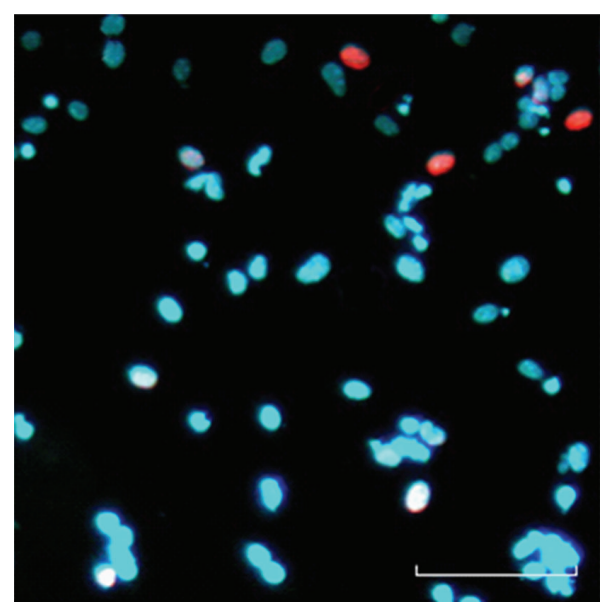

(b)

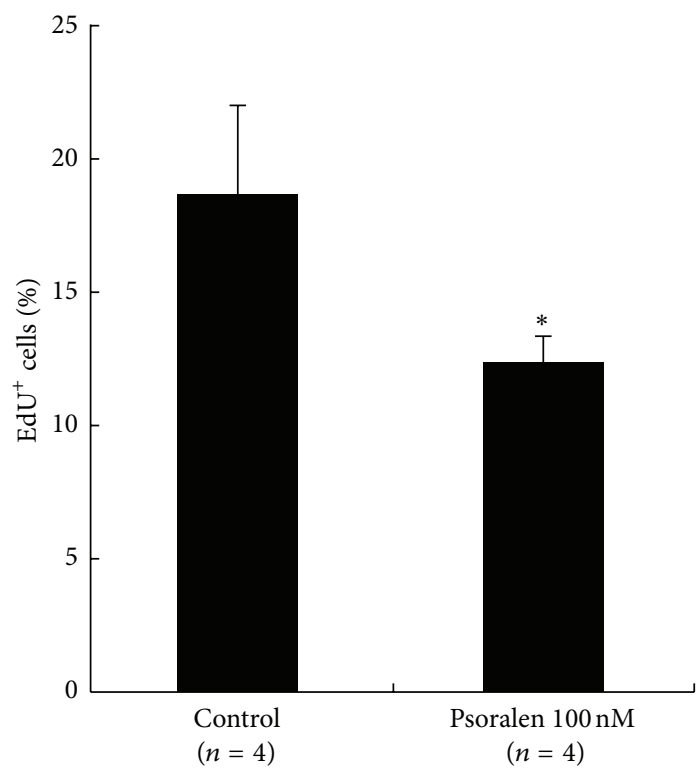

(c) $\%$ of $\mathrm{EDU}^{+}$cells

FIGURE 2: Effects of Psoralen on the proliferation of NSC. Single NSCs were plated at a density of 5000 cells per well in PDL-coated 96-well plate for $12 \mathrm{~h}$. Then, cells were subjected to $10 \mathrm{nM}$ EdU for $2 \mathrm{~h}$, followed by addition of $100 \mathrm{nM} \mathrm{OA}$ (b) or not (a). Then Edu immunofluorescence analysis was performed. The cell nuclei were counterstained with DAPI. The percentage of EdU-positive cells in total of 1000 cells was calculated. As a result, Psoralen significantly inhibited the DNA incorporation (c). Scale bars: $100 \mu \mathrm{m}$. Results were expressed as mean \pm S.D. from four independent experiments. ${ }^{*} P<0.05$ versus control.

The expression of TuJ1 protein, a neuron-specific marker, was slightly decreased (Figure $3(\mathrm{f})$ ). These results suggested that Psoralen induces the differentiation of NSC to astrocytes.

3.4. Microarray and Data Analysis. We screened the differential expression of genes that were induced by Psoralen using the microarray technique. A total of 129 genes were upregulated by Psoralen by more than 1.5 -fold compared to the control group $(P<0.05)$, and 146 genes were downregulated by more than 1.5 -fold $(P<0.05)$.

\subsection{Confirmation of Differentially Expressed Genes Using} Quantitative Real-Time PCR. We confirmed the mRNA expression of CREM, Kit1, Shh, TBX1, Bcl2l11 using quantitative real-time PCR, and these genes were chosen based on the gene function after bioinformatic analyses. The results were a highly consistent with the DNA microarray measurements (Figure 4). CREM (cAMP responsive element modulator) encodes a ZIP transcription factor that binds to the cAMP-responsive element in many viral and cellular promoters. Kit1 (Kit ligand), otherwise known as Stem cell factor or Steel factor, is a growth factor important for the survival, proliferation, and differentiation of hematopoietic stem cells and other progenitor cells. Shh (Sonic hedgehog) is a secreted protein that is required to establish patterns of cellular growth and differentiation within ventral regions of the developing CNS. TBX1 (T-box-1) plays an important role in developmental processes. The fourth gene encodes Bcl2l11 (BCL2like 11, apoptosis facilitator), regulates, and contributes to programmed cell death and apoptosis. The expression profiles 


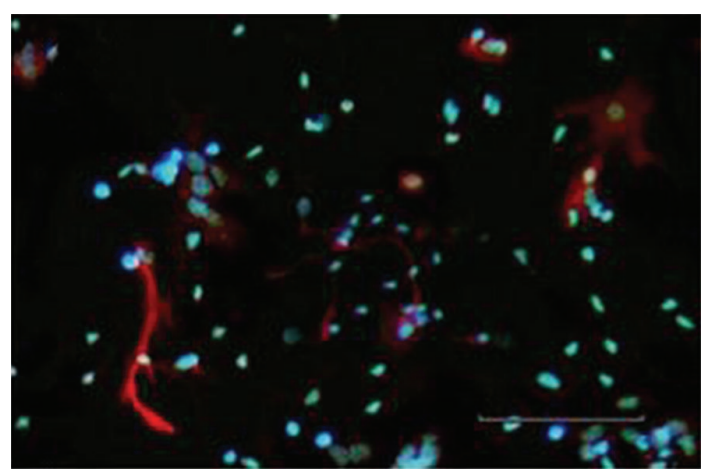

(a)

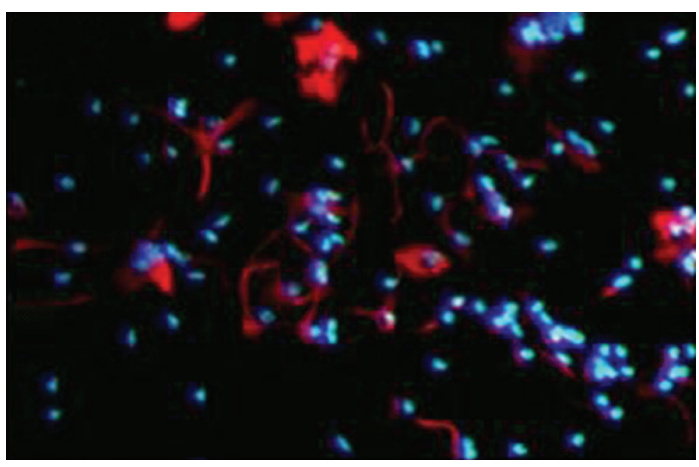

(c)

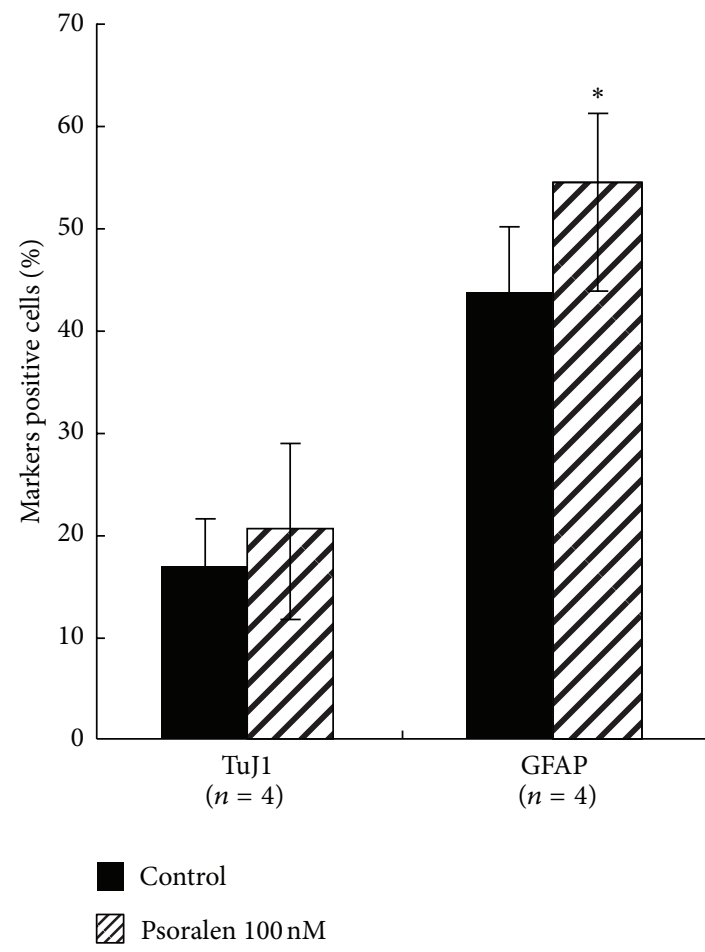

(e)

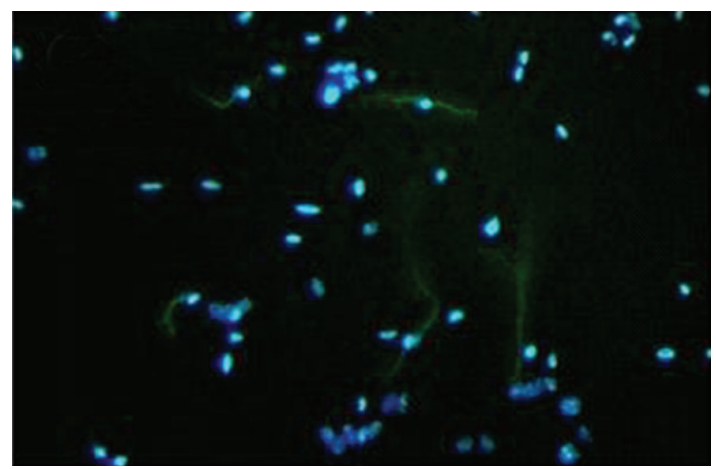

(b)

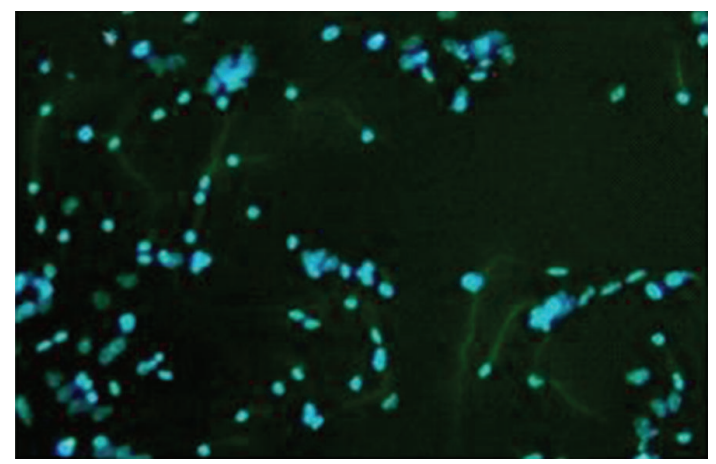

(d)

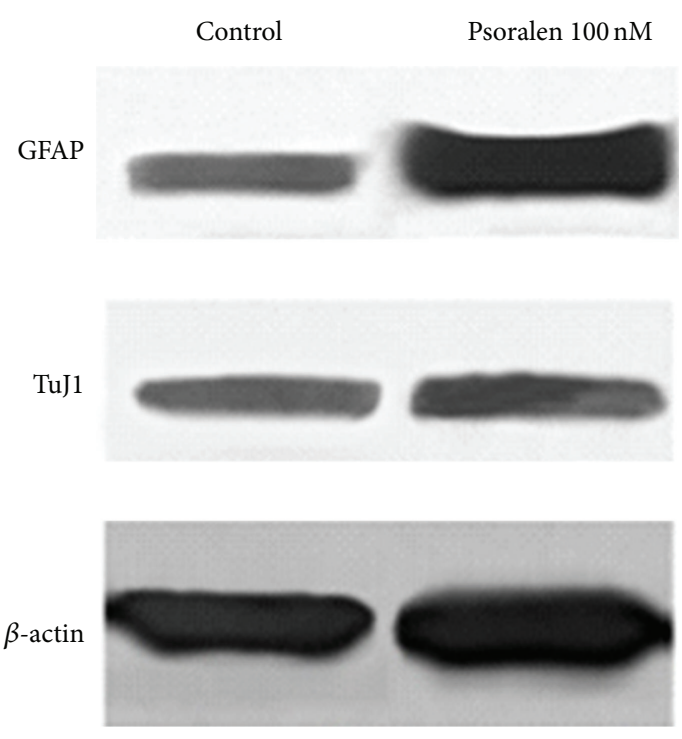

(f)

FIGURE 3: Effects of Psoralen on the differentiation of NSC. Single NSCs were seeded at a density of 50 cells/ $\mu$ L in PDL-coated 96-well plate in differentiation medium for $48 \mathrm{~h}$ without Psoralen ( $\mathrm{a}, \mathrm{b})$ or with $100 \mathrm{nM}$ Psoralen (c, d). Cells were subjected to primary antibodies of GFAP, $\mathrm{TuJ} 1$ and corresponding secondary antibodies and visualized with Alexa-conjugated $594 \mathrm{~F}(\mathrm{ab})^{\prime} 2$ goat anti-rabit antibody and 488 Alexaconjugated goat anti mouse IgG $(\mathrm{H}+\mathrm{L})$. The ratio of GFAP, TuJ1-positive cells against DAPI-stained cells was calculated. Psoralen significantly increased the GFAP-positive cells and decreased the TuJ1-positive cells (e). The same cells were performed using Western blotting. Psoralen significantly increased the GFAP, decreased the TuJ1 protein expression (f). Scale bars: $100 \mu \mathrm{m}$. Results were expressed as mean \pm S.D. from three independent experiments. ${ }^{*} P<0.05$ versus control. 


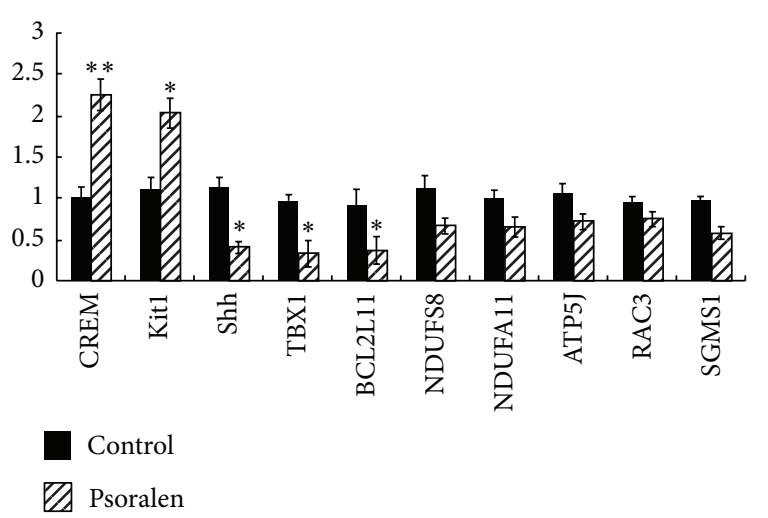

FIgURE 4: The expression profiles of these representative genes including CREM, Kit1, Shh, TBX1, and Bcl2l11 were confirmed by quantitative real-time PCR, which validates our data. Our data sets could be used for further bioinformatic analyses.

of these representative genes using quantitative real-time PCR analysis corresponded to the microarray profiles, which validates our data.

3.6. Comparisons of the DAVID Gene Functional Classification. A total of 276 known genes with different genebank accession numbers were assigned to the data sets using the DAVID Functional Annotation Tool for the functional annotation of the differentially expressed genes. The 261 systemrecognized genes were functionally classified into 7 groups using the default settings (medium classification stringency), and the corresponding enrichment scores were greater than 1. These groups included "apoptosis" (12 genes), "regulation of apoptosis" (11 genes), "multicellular organism reproduction" (10 genes), "cellular protein catabolic process" (9 genes), "epidermis development" (4 genes), "cell differentiation" (3 genes), and "regulation of cell cycle process" (3 genes). The details of the differentially expressed genes are listed in Table 1.

3.7. DAG Analysis of Gene Categories. DAG visualized enriched gene categories. Ten GO categories were enriched after Psoralen treatment, including "establishment of cell polarity" (2 genes), "myotube differentiation" (2 genes), "positive regulation of angiogenesis" (2 genes), "glycolipid metabolic process" (2 genes), "regulation of pigmentation during development" (2 genes), "negative regulation of DNA metabolic process" (2 genes), "microtubule polymerization or depolymerization" (2 genes), "telomere organization" (2 genes), "mesenchymal cell development" (3 genes), and "neural crest cell differentiation" (3 genes). The details of the differentially expressed genes are listed in Table 2.

3.8. Identification of KEGG Pathways. KEGG pathway analysis was assigned using the DAVID annotation tool to reveal the functional roles of the differentially expressed genes. Twenty-nine KEGG pathways were matched to the differentially expressed tags of the two groups, such as "Hedgehog signaling pathway", "Oxidative phosphorylation", and "Wnt signaling pathway". The details of the differentially expressed genes are listed in Table 3. The Hedgehog signaling pathway is a key regulator of animal development, and it also plays an important role in the development of adult NSC. Oxidative phosphorylation is an important metabolic pathway for cellular respiration, glycolysis, and the Krebs cycle. The Wnt signaling pathway plays a key role in cellular differentiation, apoptosis, and development.

3.9. Identification of Transcription Factor Binding Sites. oPOSSUM is a web-based system for the detection of overrepresented transcription factor binding sites in the promoters of gene sets [27]. A total of 171 transcription factors were identified in this study, including the gene families of "Ets" "BetaBetaAlpha-zinc finger," "TATA-binding," "HelixLoop-Helix," and "Hormone-nuclear Receptor". The details of the differentially expressed genes are listed in Table 4. The transcription factor, Sfpil_1(PU.1), targeted 139 genes, which may encode an ETS-domain transcription factor that is critical for the determination of cell lineage and the regulation of differentiation versus stem cell proliferation [28]. Recent research indicates that Sfpil_1 controls dendritic cell development in a dose-dependent manner [29].

\section{Discussion}

NSCs open a new way of treatment of the injured central nervous system and neurodegenerative disorders. Potential uses of NSC in repair include transplantation to repair missing cells and the activation of endogenous cells to provide "self-repair." Before the full potential of NSC can be realized, we need to know what controls their proliferation and differentiation. Precise control of proliferation and differentiation of multipotent NSC is crucial for proper development of the nervous system. Chinese herb extracts as effective factors regulating the self-renewal and differentiation capacity of NSC have been widely studied [8]. Psoralen can modulate the proliferation and differentiation of a variety of stem cells through different mechanisms [19-21].

In the present study, single cells derived from dissected neural tissue form floating balls of cells, termed neurospheres, when plated under nonadherent, permissive conditions [30]. These highly heterogeneous structures contain neural stem cells, more restricted progenitors, and differentiated progeny. The more restricted progenitors and differentiated progeny exhibit limited proliferation capacity, and these cells only form very small neurospheres. However, the neural stem cells demonstrate strong self-renewal and generate neurospheres in continuous passages. The self-renewal potential of cells within neurosphere cultures may be investigated by the dissociation of single cells that must be plated at a density at which a single cell gives rise to a single neurosphere. This process is termed clonal analysis. Single cells that are plated under medium to high cell densities permit the adherence of cells or small neurospheres to each other, and these structures combine to form larger neurospheres [31, 32]. Clonal analysis is impossible in this situation, and the true proliferative capacity of stem cells cannot be properly determined. However, drug-screening assays do not require that 
TABLE 1: The list of the differentially expressed tags of DAVID gene functional classification.

\begin{tabular}{|c|c|c|c|}
\hline $\begin{array}{l}\text { Functional } \\
\text { annotation clustering }\end{array}$ & $\begin{array}{c}\text { Gene } \\
\text { number }\end{array}$ & $\begin{array}{l}\text { Gene bank } \\
\text { accession }\end{array}$ & Description \\
\hline \multirow{12}{*}{ Apoptosis } & \multirow{12}{*}{12} & ВC058175 & BCL2-like 11 (apoptosis facilitator) \\
\hline & & AK144648 & CASP2 and RIPK1 domain containing adaptor with death domain \\
\hline & & AK186862 & Cytokine-induced apoptosis inhibitor 1 \\
\hline & & AK049134 & Ectodysplasin A2 isoform receptor \\
\hline & & AK010878 & Hypothetical protein LOC100233175 \\
\hline & & AK041961 & Kit ligand \\
\hline & & XM_001476612 & Predicted gene 15753, Sp110 nuclear body protein \\
\hline & & BC016606 & $\begin{array}{l}\text { Proteasome (prosome, macropain) assembly chaperone 2, similar to Clast } 3 \\
\text { protein }\end{array}$ \\
\hline & & BC063087 & Sonic hedgehog \\
\hline & & AK082974 & Sphingomyelin synthase 1 \\
\hline & & BC027335 & Tectonic family member 3 \\
\hline & & AK183781 & Zinc finger, DHHC domain containing 16 \\
\hline \multirow{11}{*}{$\begin{array}{l}\text { Regulation of } \\
\text { apoptosis }\end{array}$} & \multirow{11}{*}{11} & BC058175 & BCL2-like 11 (apoptosis facilitator) \\
\hline & & AK144648 & CASP2 and RIPK1 domain containing adaptor with death domain \\
\hline & & AK186862 & Cytokine-induced apoptosis inhibitor 1 \\
\hline & & ВС080315 & Glutamate receptor, metabotropic 7 \\
\hline & & BC152841 & Heat shock protein $1 \mathrm{~B}$, heat shock protein $1 \mathrm{~A}$, heat shock protein 1-like \\
\hline & & AK010878 & Hypothetical protein LOC100233175 \\
\hline & & AK041961 & Kit ligand \\
\hline & & AK160757 & Microphthalmia-associated transcription factor \\
\hline & & XM_001476612 & Sp110 nuclear body protein \\
\hline & & BC016606 & $\begin{array}{l}\text { Proteasome (prosome, macropain) assembly chaperone } 2 \text {; similar to Clast } 3 \\
\text { protein }\end{array}$ \\
\hline & & AK082974 & Sphingomyelin synthase 1 \\
\hline \multirow{10}{*}{$\begin{array}{l}\text { Multicellular } \\
\text { organism } \\
\text { reproduction }\end{array}$} & \multirow{10}{*}{10} & BC058175 & BCL2-like 11 (apoptosis facilitator) \\
\hline & & AK086849 & beta-1,4-N-Acetyl-galactosaminyl transferase 1 \\
\hline & & AY738720 & cAMP responsive element modulator \\
\hline & & BC152841 & Heat shock protein $1 \mathrm{~B}$, heat shock protein $1 \mathrm{~A}$, heat shock protein 1-like \\
\hline & & AK160943 & Heterogeneous nuclear ribonucleoprotein L-like, glutathione peroxidase 4 \\
\hline & & AK041961 & Kit ligand \\
\hline & & AK078529 & Neuralized homolog 1A (Drosophila); similar to neuralized 1 \\
\hline & & XM_001474694 & Rik protein \\
\hline & & BC115962 & Germ cell-less homolog 1 \\
\hline & & BC061175 & Testis-specific serine kinase 2 \\
\hline \multirow{9}{*}{$\begin{array}{l}\text { Cellular protein } \\
\text { catabolic process }\end{array}$} & \multirow{9}{*}{9} & BC058593 & SUMO1/sentrin specific peptidase 7 \\
\hline & & AK053749 & WW domain containing E3 ubiquitin protein ligase 2 \\
\hline & & BC040367 & Ligand of numb-protein X 1 \\
\hline & & BC128498 & Myosin, heavy polypeptide 9 , nonmuscle \\
\hline & & BC115962 & Germ cell-less homolog 1 \\
\hline & & XM_001474694 & Rik protein \\
\hline & & XM_354829 & Seven in absentia homolog 3 (Drosophila) \\
\hline & & ВC059027 & Similar to midline 1 , midline 1 \\
\hline & & BC026983 & Ubiquitin specific peptidase 39 \\
\hline
\end{tabular}


TABle 1: Continued.

\begin{tabular}{|c|c|c|c|}
\hline $\begin{array}{l}\text { Functional } \\
\text { annotation clustering }\end{array}$ & $\begin{array}{c}\text { Gene } \\
\text { number }\end{array}$ & $\begin{array}{l}\text { Gene bank } \\
\text { accession }\end{array}$ & Description \\
\hline \multirow{4}{*}{$\begin{array}{l}\text { Epidermis } \\
\text { development }\end{array}$} & \multirow{4}{*}{4} & BC152326 & Involucrin, RIKEN cDNA 1110019C06 gene \\
\hline & & BC148438 & $\begin{array}{l}\text { Small proline-rich protein } 2 \mathrm{E} \text {, small proline-rich protein } 2 \mathrm{~F} \text {, Small proline-rich } \\
\text { protein } 2 \mathrm{I}\end{array}$ \\
\hline & & BC156163 & Small proline-rich protein $2 \mathrm{H}$ \\
\hline & & ВC063087 & Sonic hedgehog \\
\hline \multirow{3}{*}{ Cell differentiation } & \multirow{3}{*}{3} & AK041961 & Kit ligand \\
\hline & & AF349658 & Similar to T-box 1; T-box 1 \\
\hline & & ВC063087 & Sonic hedgehog \\
\hline \multirow{3}{*}{$\begin{array}{l}\text { Regulation of cell } \\
\text { cycle process }\end{array}$} & \multirow{3}{*}{3} & AK018243 & ZW10 homolog (Drosophila), centromere/kinetochore protein \\
\hline & & BC016606 & $\begin{array}{l}\text { Proteasome (prosome, macropain) assembly chaperone } 2 \text {, similar to Clast } 3 \\
\text { protein }\end{array}$ \\
\hline & & AK003451 & Timeless interacting protein \\
\hline
\end{tabular}

TABLE 2: The list of the differentially expressed tags of DAG analysis of gene categories.

\begin{tabular}{|c|c|c|}
\hline Categories & $\begin{array}{l}\text { Gene bank } \\
\text { accession }\end{array}$ & Description \\
\hline \multirow{2}{*}{ Establishment of cell polarity } & 17886 & Myosin, heavy polypeptide 9 , nonmuscle \\
\hline & 20423 & Sonic hedgehog \\
\hline \multirow{2}{*}{ Myotube differentiation } & 17886 & Myosin, heavy polypeptide 9 , nonmuscle \\
\hline & 20423 & Sonic hedgehog \\
\hline \multirow{2}{*}{ Positive regulation of angiogenesis } & 14461 & GATA binding protein 2 \\
\hline & 12394 & Runt-related transcription factor 1 \\
\hline \multirow{2}{*}{ Glycolipid metabolic process } & 14421 & beta-1,4-N-Acetyl-galactosaminyl transferase 1 \\
\hline & 12916 & cAMP responsive element modulator \\
\hline \multirow{2}{*}{$\begin{array}{l}\text { Regulation of pigmentation during } \\
\text { development }\end{array}$} & 12125 & BCL2-like 11 (apoptosis facilitator) \\
\hline & 17311 & Kit ligand \\
\hline \multirow{2}{*}{$\begin{array}{l}\text { Negative regulation of DNA metabolic } \\
\text { process }\end{array}$} & 66131 & Timeless interacting protein \\
\hline & 72836 & Protection of telomeres $1 \mathrm{~B}$ \\
\hline \multirow{2}{*}{$\begin{array}{l}\text { Microtubule polymerization or } \\
\text { depolymerization }\end{array}$} & 17318 & Midline 1 \\
\hline & 17997 & Neural precursor cell expressed, developmentally downregulated gene 1 \\
\hline \multirow{2}{*}{ Telomere organization } & 15511 & Heat shock protein $1 \mathrm{~B}$ \\
\hline & 72836 & Protection of telomeres $1 \mathrm{~B}$ \\
\hline \multirow{3}{*}{ Mesenchymal cell development } & 21380 & T-box 1 \\
\hline & 20423 & Sonic hedgehog \\
\hline & 17311 & Kit ligand \\
\hline \multirow{3}{*}{ Neural crest cell differentiation } & 21380 & T-box 1 \\
\hline & 20423 & Sonic hedgehog \\
\hline & 17311 & Kit ligand \\
\hline
\end{tabular}

each neurosphere derived from a single stem or progenitor cell. A low plating cell density of 5000 cells $/ \mathrm{mL}$ or 1000 cells $/ \mathrm{mL}$ is sufficient to measure the self-renewal of neural stem cells $[33,34]$.

We plated single cells at a density of 5000 cells $/ \mathrm{mL}$ in $100 \mu \mathrm{L} /$ well in a 96-well plate. Approximately 5\% of the plated single cells reformed neurospheres, which is consistent with previous studies. Psoralen significantly inhibited neurosphere formation with maximum effects at $100 \mathrm{nM}$.
This Psoralen-induced decrease in neurosphere formation may be derived from the compromised proliferation of NSC. Therefore, we investigated NSC proliferation in the presence of Psoralen using an EdU incorporation assay. Psoralen significantly reduced EdU incorporation. These results suggested that Psoralen inhibits the self-renewal of NSC through the inhibition of proliferation.

NSCs generally and gradually exit the cell cycle when they enter the process of differentiation. The length of the neural 
TABLE 3: The list of the differentially expressed tags of matched KEGG pathway analysis.

\begin{tabular}{|c|c|c|c|}
\hline KEGG pathways & $\begin{array}{c}\text { Gene number } \\
\text { matched }\end{array}$ & $\begin{array}{l}\text { Gene bank } \\
\text { accession }\end{array}$ & Description \\
\hline \multirow{5}{*}{ MAPK signaling pathway } & \multirow{5}{*}{5} & BC119041 & RAS-related C3 botulinum substrate 3 \\
\hline & & BC052705 & Dual specificity phosphatase 8 \\
\hline & & BC152841 & Heat shock protein $1 \mathrm{~B}$ \\
\hline & & BC006037 & Mitogen-activated protein kinase kinase kinase kinase 3 \\
\hline & & BC054533 & Protein kinase, cAMP dependent, catalytic, beta \\
\hline \multirow{5}{*}{ Pathways in cancer } & \multirow{5}{*}{5} & BC119041 & RAS-related C3 botulinum substrate 3 \\
\hline & & AK041961 & Kit ligand \\
\hline & & AK160757 & Microphthalmia-associated transcription factor \\
\hline & & AK155262 & Runt-related transcription factor 1 \\
\hline & & BC063087 & Sonic hedgehog \\
\hline \multirow{4}{*}{ Spliceosome } & \multirow{4}{*}{4} & AK040680 & Cell division cycle 40 homolog (yeast) \\
\hline & & BC152841 & Heat shock protein $1 \mathrm{~B}$ \\
\hline & & BC004793 & Poly(rC) binding protein 1 \\
\hline & & ВC026983 & Ubiquitin specific peptidase 39 \\
\hline \multirow{4}{*}{ Axon guidance } & \multirow{4}{*}{4} & AK089130 & Eph receptor A5 \\
\hline & & BC119041 & RAS-related C3 botulinum substrate 3 \\
\hline & & AK171860 & Actin-binding LIM protein 1 \\
\hline & & AK053689 & Netrin G1 \\
\hline \multirow{3}{*}{$\begin{array}{l}\text { Hedgehog signaling } \\
\text { pathway }\end{array}$} & \multirow{3}{*}{3} & AK149310 & Casein kinase 1 , gamma 1 \\
\hline & & ВC054533 & Protein kinase, cAMP dependent, catalytic, beta \\
\hline & & BC063087 & Sonic hedgehog \\
\hline \multirow{3}{*}{ Viral myocarditis } & \multirow{3}{*}{3} & BC119041 & RAS-related C3 botulinum substrate 3 \\
\hline & & BC128498 & Myosin, heavy polypeptide 9 , nonmuscle \\
\hline & & BC156199 & v-abl Abelson murine leukemia viral oncogene homolog 2 \\
\hline \multirow{3}{*}{ Melanogenesis } & \multirow{3}{*}{3} & AK041961 & Kit ligand \\
\hline & & AK160757 & Microphthalmia-associated transcription factor \\
\hline & & BC054533 & Protein kinase, cAMP dependent, catalytic, beta \\
\hline \multirow{3}{*}{ Oxidative phosphorylation } & \multirow{3}{*}{3} & AK078484 & ATP synthase \\
\hline & & XM_895878 & NADH dehydrogenase (ubiquinone) 1 alpha subcomplex 11 \\
\hline & & AK149674 & NADH dehydrogenase (ubiquinone) Fe-S protein 8 \\
\hline \multirow{3}{*}{$\begin{array}{l}\text { Cytokine-cytokine receptor } \\
\text { interaction }\end{array}$} & \multirow{3}{*}{3} & AK049134 & Ectodysplasin A2 isoform receptor \\
\hline & & AY221616 & Interleukin 15 receptor, alpha chain \\
\hline & & AK041961 & Kit ligand \\
\hline \multirow{2}{*}{$\begin{array}{l}\text { Cysteine and methionine } \\
\text { metabolism }\end{array}$} & \multirow{2}{*}{2} & AK085987 & 5-Methyltetrahydrofolate-homocysteine methyltransferase \\
\hline & & ВC094469 & Mercaptopyruvate sulfurtransferase \\
\hline \multirow{2}{*}{ Prion diseases } & \multirow{2}{*}{2} & BC152841 & Heat shock protein $1 \mathrm{~B}$ \\
\hline & & BC054533 & Protein kinase, cAMP dependent, catalytic, beta \\
\hline \multirow{2}{*}{$\begin{array}{l}\text { SNARE interactions in } \\
\text { vesicular transport }\end{array}$} & \multirow{2}{*}{2} & AK030538 & Vesicle transport through interaction with t-SNAREs homolog $1 \mathrm{~A}$ \\
\hline & & BC086925 & Vesicle-associated membrane protein 5 \\
\hline Adherens junction & 2 & AK137694 & LIM domain only 7 \\
\hline & & BC119041 & RAS-related C 3 botulinum substrate 3 \\
\hline Gap junction & 2 & AK031305 & Guanylate cyclase 1, soluble, alpha 3 \\
\hline & & BC054533 & Protein kinase, cAMP dependent, catalytic, beta \\
\hline Systemic lupus & 2 & BC152885 & Histone $\mathrm{H} 4$ \\
\hline erythematosus & 2 & K02799 & Complement $\mathrm{C} 4$ precursor \\
\hline
\end{tabular}


TABLe 3: Continued.

\begin{tabular}{|c|c|c|c|}
\hline KEGG pathways & $\begin{array}{c}\text { Gene number } \\
\text { matched }\end{array}$ & $\begin{array}{l}\text { Gene bank } \\
\text { accession }\end{array}$ & Description \\
\hline \multirow{2}{*}{$\begin{array}{l}\text { Vascular smooth muscle } \\
\text { contraction }\end{array}$} & \multirow{2}{*}{2} & AK031305 & Guanylate cyclase 1 , soluble, alpha 3 \\
\hline & & BC054533 & Protein kinase, cAMP dependent, catalytic, beta \\
\hline \multirow{2}{*}{$\begin{array}{l}\text { Natural killer cell mediated } \\
\text { cytotoxicity }\end{array}$} & \multirow{2}{*}{2} & BC119041 & RAS-related C3 botulinum substrate 3 \\
\hline & & AY860969 & Natural killer cell receptor Ly49C \\
\hline \multirow{2}{*}{ Parkinson's disease } & \multirow{2}{*}{2} & AK078484 & ATP synthase \\
\hline & & AK149674 & NADH dehydrogenase (ubiquinone) Fe-S protein 8 \\
\hline \multirow{2}{*}{ Tight junction } & \multirow{2}{*}{2} & BC002003 & Claudin 1 \\
\hline & & BC128498 & Myosin, heavy polypeptide 9 , non-muscle \\
\hline \multirow{2}{*}{$\begin{array}{l}\text { Ubiquitin mediated } \\
\text { proteolysis }\end{array}$} & \multirow{2}{*}{2} & AK053749 & WW domain containing E3 ubiquitin protein ligase 2 \\
\hline & & BC059027 & Midline 1 \\
\hline \multirow{2}{*}{ Insulin signaling pathway } & \multirow{2}{*}{2} & BC054533 & Protein kinase, cAMP dependent, catalytic, beta \\
\hline & & AK172276 & Regulatory associated protein of MTOR, complex 1 \\
\hline \multirow{2}{*}{ Wnt signaling pathway } & \multirow{2}{*}{2} & BC119041 & RAS-related C3 botulinum substrate 3 \\
\hline & & BC054533 & Protein kinase, cAMP dependent, catalytic, beta \\
\hline \multirow{2}{*}{ Purine metabolism } & \multirow{2}{*}{2} & AK031305 & Guanylate cyclase 1 , soluble, alpha 3 \\
\hline & & AK036090 & Phosphodiesterase 8B \\
\hline \multirow{2}{*}{ Alzheimer's disease } & \multirow{2}{*}{2} & AK078484 & ATP synthase \\
\hline & & AK149674 & NADH dehydrogenase (ubiquinone) $\mathrm{Fe}-\mathrm{S}$ protein 8 \\
\hline \multirow{2}{*}{$\begin{array}{l}\text { Chemokine signaling } \\
\text { pathway }\end{array}$} & \multirow{2}{*}{2} & BC010478 & Hemopoietic cell kinase \\
\hline & & BC054533 & Protein kinase, cAMP dependent, catalytic, beta \\
\hline \multirow{2}{*}{ Huntington's disease } & \multirow{2}{*}{2} & AK078484 & ATP synthase \\
\hline & & AK149674 & NADH dehydrogenase (ubiquinone) $\mathrm{Fe}-\mathrm{S}$ protein 8 \\
\hline \multirow{2}{*}{$\begin{array}{l}\text { Regulation of actin } \\
\text { cytoskeleton }\end{array}$} & \multirow{2}{*}{2} & BC119041 & RAS-related C3 botulinum substrate 3 \\
\hline & & BC128498 & Myosin, heavy polypeptide 9 , non-muscle \\
\hline \multirow{2}{*}{$\begin{array}{l}\text { Neuroactive } \\
\text { ligand-receptor interaction }\end{array}$} & \multirow{2}{*}{2} & AK050472 & Gastric inhibitory polypeptide receptor \\
\hline & & BC080315 & Glutamate receptor, metabotropic 7 \\
\hline \multirow{2}{*}{ Olfactory transduction } & \multirow{2}{*}{2} & BC104278 & Olfactory receptor 1173 \\
\hline & & BC054533 & Protein kinase, cAMP dependent, catalytic, beta \\
\hline
\end{tabular}

progenitor cell cycle is directly coupled to cell fate choices because factors that shorten the cell cycle inhibit differentiation divisions, but factors that lengthen the cell cycle promote differentiation divisions. We also investigated the effect of Psoralen on NSC differentiation. Psoralen increased the percentage of GFAP-positive cells, but the percentage of TuJ1-positive cells was not altered. Psoralen increased GFAP protein expression on Western blots, but it did not influence TuJ1 protein expression. Our experiment demonstrated that Psoralen strongly induced the differentiation of NSC into astrocytes.

A cluster analysis was performed on these differentially expressed genes using DAVID bioinformatics resources. DAVID functional classification suggested that Psoralen primarily altered the expression of genes involved in differentiation, proliferation, apoptosis, and catabolism. The DAG analysis suggested that the effect of Psoralen on neural stem cells is a biological process that impacts the metabolism of DNA, sugar, and lipids and regulates cellular proliferation, split polarization, and differentiation.
There are several genes of interest in the DAVID and DAG classification, including BCL2-like 11, Kit ligand, and Sonic hedgehog, which were confirmed by our previous quantitative real-time PCR test. BCL2-like 11 protein is encoded by a gene in the BCL-2 protein family, which play important roles in the regulation of neuronal and lymphocytic apoptosis. BCL-2 deficiency does not affect neuronal numbers in the cerebellum [35], but this protein has been implicated in hippocampal neuronal protection in a seizure model [36]. BCL-2-deficient mice exhibit relatively normal development of the nervous system, but BCL-2 is important for the postnatal maintenance of specific neuronal subsets, including facial motor neurons and dorsal root ganglia [37]. Kit ligand, also known as stem cell factor (SCF), steel factor (SLF) and mast cell growth factor (MGF), is as 30-kDa glycoprotein with broad activity in various tissues [38]. Kit ligand regulates the development of cellular lineage by expressing c-kit, which affects proliferation and maturation $[38,39]$. Kit signaling in the CNS influences oligodendrocyte precursors prior to differentiation towards a myelinated phenotype [39]. Greater 
TABLE 4: The list of the differentially expressed tags of matched transcription factor binding sites.

\begin{tabular}{|c|c|c|}
\hline Transcription factor & Gene family & $\begin{array}{c}\text { Target gene } \\
\text { (>70 hits) }\end{array}$ \\
\hline Sfpil_1 & Ets & 139 \\
\hline Elf3_1 & Ets & 131 \\
\hline Zfp105_1 & Beta-Beta-Alpha-zinc finger & 114 \\
\hline Tbp_1 & TATA binding & 110 \\
\hline Foxj1_1 & Forkhead & 100 \\
\hline Sox12_1 & High-mobility group & 95 \\
\hline Tcfap2a_1 & Helix-Loop-Helix & 94 \\
\hline Zic2_2 & Beta-Beta-Alpha-zinc finger & 93 \\
\hline Irf3_1 & IRF & 92 \\
\hline Foxj3_2 & Forkhead & 91 \\
\hline Zic3_2 & Beta-Beta-Alpha-zinc finger & 89 \\
\hline Sox11_1 & High-mobility group & 89 \\
\hline Sox4_1 & High-mobility group & 86 \\
\hline Klf7_1 & Beta-Beta-Alpha-zinc finger & 85 \\
\hline Arid5a_1 & Arid & 83 \\
\hline Ehf_1 & Ets & 83 \\
\hline Sox11_2 & High-mobility group & 80 \\
\hline Sox18_1 & High-mobility group & 80 \\
\hline Osr1_2 & Beta-Beta-Alpha-zinc finger & 79 \\
\hline Sox5_1 & High-mobility group & 79 \\
\hline Sp4_1 & Beta-Beta-Alpha-zinc finger & 77 \\
\hline Zscan4_2 & Beta-Beta-Alpha-zinc finger & 76 \\
\hline Tcfap2e_1 & Helix-Loop-Helix & 76 \\
\hline Egr1_2 & Beta-Beta-Alpha-zinc finger & 75 \\
\hline Foxl1_2 & Forkhead & 75 \\
\hline Foxa2_1 & Forkhead & 75 \\
\hline Tcfap2c_1 & Helix-Loop-Helix & 75 \\
\hline Sox14_2 & High-mobility group & 75 \\
\hline Smad3_1 & MH1 & 75 \\
\hline Sox17_1 & High-mobility group & 74 \\
\hline Hicl_2 & Beta-Beta-Alpha-zinc finger & 73 \\
\hline Sox $21 \_2$ & High-mobility group & 72 \\
\hline Zic1_2 & Beta-Beta-Alpha-zinc finger & 71 \\
\hline Tcf1_2 & Homeo & 71 \\
\hline Zfp740_1 & Beta-Beta-Alpha-zinc finger & 70 \\
\hline
\end{tabular}

than $93 \%$ of nestin-positive NSC from the embryonic rat cortex express Kit ligand [40]. Kit ligand is a survival factor for NSPCs during the early stages of differentiation [41]. The Sonic hedgehog (Shh) gene is one of a homolog gene of Hedgehog (hh) [42]. Shh gene plays an important role in the development of the mammary glands, prostate, lung, hair, nervous system, and other organs. Shh regulates the development of the neural system, especially the proliferation and differentiation of neural stem cells $[43,44]$. Shh is a positive regulator of adult hippocampal neural stem cell proliferation, and it may participate in injury remodeling.

We further searched the possible transcription factor binding sites existing in the upstream sequences of differentially expressed genes. Consequently, 139 genes differentially expressed were predicted to have transcription factor binding sites for Sfpil, a member of the Ets family. The common character of Ets factors was highly conserved and the DNA binding domain can combine with specific gene sequence to regulate the expression and function of target gene by being involved in cell proliferation, differentiation, apoptosis, and mesenchymal-epithelial interactions $[45,46]$. ETs could be involved in many physiological and pathological processes. A large number of researches showed that Ets transcription factors play an important regulation role in the development, tumor invasion, and metastasis of amphibians, birds and mammals [47].

Sfpil, also called PU.1, belongs to the SpI subfamily of the Ets family. The transcription factors Sfpi2, Sfpi3 also belong to the same family. These members all showed the existence of the Ets structure domain in the C-terminal of the protein and an acid transcription activation structure domain in the N-terminal. Literature study reported that this kind of structure played an important role in the differentiation process of a variety of cells. The changes of the expression quantity of the transcription factors played a decisive role in adjusting the differentiation direction of stem cells [48]. Sfpil was highly expressed in myeloid cells but not in lymphocyte. It functioned in the early state of differentiation in granulocyte, red blood cells, and megakaryocyte, and it suppressed red blood cell differentiating to red blood cells. Studies [28] have shown that a high level of Sfpil could cause differentiation of macrophage but not proliferation of progenitor cells. In embryogenesis process, lack of Sfpil could lead to development delay $[49,50]$. In recent years, study [29] showed that Sfpil also played an essential role in differentiation of dendritic cells. Based on bioinformatical analysis and the literature review, we thought that Sfpil may mediate the effects of Psoralen.

The KEGG pathway analysis demonstrated that the effects of Psoralen on neural stem cells were closely related to the Hedgehog signaling pathway, Wnt signaling pathways, MAPK, spliceosomes, axon guidance, oxidative phosphorylation, adherens junction, gap junction, and tight junction. The matched Hedgehog signaling pathway is of interest, which is crucial for the generation and maintenance of both embryonic and adult stem cells. This pathway regulates spinal dorsal-ventral plasticity and the multizone of neural precursor cell proliferation and differentiation in the developing nervous system. Hedgehog signaling pathway also plays a key role in the regulation of neural progenitor cell growth [51]. Granule cell precursor proliferation in the cerebellum requires Hedgehog signaling [52]. Hedgehog signaling may regulate the self-renewal of progenitor cells in the SVZ, hippocampus, olfactory bulb, and other brain areas [51, 53]. The downstream target gene of the Hedgehog pathway, BMIl, regulates central and peripheral nervous system progenitor cell self-renewal [54]. The oligodendrocyte generation of glial precursor cells and the subsequent differentiation into mature 
oligodendrocytes require Hedgehog signaling in $\mathrm{SHH}^{(-/-)}$ mutants [55]. Cell proliferation and differentiation culture conditions in the NSC clones express $\mathrm{mRNA}$ of the functional Shh receptor, PTCH, and Shh $(5 \sim 50 \mathrm{nmol} / \mathrm{L})$ in vitro promotes the proliferation of fetal rat spinal cord in primary and passaged neural stem cells in a dose-dependent manner. This activation is also observed in quiescent adult neural stem cells in which the Hedgehog signal pathway stimulates continuous proliferation and differentiation [56].

Recently, Crosstalk of Hedgehog with other critical signaling pathways has been mentioned. Hedgehog and Wnt pathways resulted in opposite proliferative outcomes of neural stem/progenitor cells, and Sfrp-1 and Gli3 contributed to this negative cross-regulation [57]. But Hedgehog and Notch signaling could cooperate to regulate neurogenic divisions of neocortical progenitors. The transcription factors Hesl and Blbp were possibly the key molecules in the $\mathrm{Hh} / \mathrm{Notch}$ coregulation of corticogenesis [58].

In conclusion, our study demonstrated the antiproliferative and prodifferentiative effects of Psoralen on NSC. The microarray study demonstrated that the gene expression profile of NSC could be specifically regulated by Psoralen. The genes involved in the classification of cellular differentiation, proliferation, and metabolism, the transcription factors belonging to Ets family, and the hedgehog pathway may play important roles in the regulation process, which need further studies.

\section{Authors' Contribution}

You Ning and Jian-Hua Huang share first authorship of this paper.

\section{Conflict of Interests}

The authors declare no financial or commercial conflict of interest.

\section{Acknowledgments}

This work was supported by the National Basic Research Program in China (no. 2010CB530402) and the National Natural Science Foundation of China (no. 81202745, and no. 31171129).

\section{References}

[1] F. H. Gage, “Mammalian neural stem cells," Science, vol. 287, no. 5457, pp. 1433-1438, 2000.

[2] C. M. Zhao, W. Deng, and F. H. Gage, "Mechanisms and functional implications of adult neurogenesis," Cell, vol. 132, no. 4, pp. 645-660, 2008.

[3] S. Lugert, O. Basak, P. Knuckles et al., "Quiescent and active hippocampal neural stem cells with distinct morphologies respond selectively to physiological and pathological stimuli and aging," Cell Stem Cell, vol. 6, no. 5, pp. 445-456, 2010.

[4] H. I. Kornblum, "Introduction to neural stem cells," Stroke, vol. 38, no. 2, pp. 810-816, 2007.
[5] J. M. Zhang, H. K. Wang, C. Q. Ye et al., "ATP released by astrocytes mediates glutamatergic activity-dependent heterosynaptic suppression,” Neuron, vol. 40, no. 5, pp. 971-982, 2003.

[6] Y. Yang, W. Ge, Y. Chen et al., "Contribution of astrocytes to hippocampal long-term potentiation through release of Dserine," Proceedings of the National Academy of Sciences of the United States of America, vol. 100, no. 25, pp. 15194-15199, 2003.

[7] C. T. Leung, P. A. Coulombe, and R. R. Reed, "Contribution of olfactory neural stem cells to tissue maintenance and regeneration," Nature Neuroscience, vol. 10, no. 6, pp. 720-726, 2007.

[8] W. Wang, W. Huang, and H. Ai, "Proliferation and differentiation of adult neural stem cell induced by traditional Chinese medicine in brain," Chinese Journal of Rehabilitation Theory and Practice, vol. 13, no. 1, pp. 26-28, 2007.

[9] L. J. Chai, P. R. Zhong, Z. H. Zhou, X. Y. Wang, T. Ishida, and Y. J. Zhang, "Proliferation effects of astragaloside on neural atem cells in vitro," Chinese Pharmacological Bulletin, vol. 26, no. 5, pp. 670-673, 2010.

[10] M. He, M. L. Liu, K. X. Wang et al., "Investigation of the directed differentiation of neural stem cells after brain-derived neurotrophic factor, salidroside and neural stem cells transplanted into epileptic rat brain," Chinese Journal of Clinical Neurosciences, vol. 20, no. 2, pp. 181-187, 2012.

[11] D. Bethea, B. Fullmer, S. Syed et al., "Psoralen photobiology and photochemotherapy: 50 years of science and medicine," Journal of Dermatological Science, vol. 19, no. 2, pp. 78-88, 1999.

[12] J. Llano, J. Raber, and L. A. Eriksson, "Theoretical study of phototoxic reactions of psoralens," Journal of Photochemistry and Photobiology A, vol. 154, no. 2-3, pp. 235-243, 2003.

[13] S. S. Yones, R. A. Palmer, T. M. Garibaldinos, and J. L. M. Hawk, "Randomized double-blind trial of treatment of vitiligo: efficacy of psoralen-UV-A therapy versus narrowband-UV-B therapy," Archives of Dermatology, vol. 143, no. 5, pp. 578-584, 2007.

[14] C. Querfeld, S. T. Rosen, T. M. Kuzel et al., "Long-term followup of patients with early-stage cutaneous T-cell lymphoma who achieved complete remission with psoralen plus UV-A monotherapy," Archives of Dermatology, vol. 141, no. 3, pp. 305311, 2005.

[15] R. S. Stern, "Psoralen and ultraviolet a light therapy for psoriasis," The New England Journal of Medicine, vol. 357, no. 7, pp. 682-690, 2007.

[16] A. B. Santamaria, D. W. Davis, D. X. Nghiem et al., "p53 and Fas ligand are required for psoralen and UVA-inducedapoptosis in mouse epidermal cells," Cell Death and Differentiation, vol. 9, no. 5, pp. 549-560, 2002.

[17] K. L. March, B. L. Patton, R. L. Wilensky, and D. R. Hathaway, "8-methoxypsoralen and longwave ultraviolet irradiation are a novel antiproliferative combination for vascular smooth muscle," Circulation, vol. 87, no. 1, pp. 184-191, 1993.

[18] T. E. Keane, J. A. Petros, B. Velimirovich, K. T. Yue, and S. D. Graham, "Methoxypsoralen phototherapy of transitional cell carcinoma," Urology, vol. 44, no. 6, pp. 842-846, 1994.

[19] J. Z. Wu, Z. Q. Situ, W. Wang, J. Chen, and B. Liu, "Antitumor activity of psoralen on mucoepidermoid carcinoma cell line MEC-1," Chinese Medical Journal, vol. 105, no. 11, pp. 913-917, 1992.

[20] S. Wu, Z. Zhang, and J. Zhao, "An experimental study on antitumor activity of psoralen on mammary cancer cell line EMT6 in vitro and in vivo," China Journal of Chinese Materia Medica, vol. 23, no. 5, pp. 303-305, 1998. 
[21] D. Z. Tang, F. Yang, Z. Yang et al., "Psoralen stimulates osteoblast differentiation through activation of BMP signaling," Biochemical and Biophysical Research Communications, vol. 405, no. 2, pp. 256-261, 2011.

[22] B. A. Reynolds and S. Weiss, "Clonal and population analyses demonstrate that an EGF-responsive mammalian embryonic CNS precursor is a stem cell," Developmental Biology, vol. 175, no. 1, pp. 1-13, 1996.

[23] A. Salic and T. J. Mitchison, "A chemical method for fast and sensitive detection of DNA synthesis in vivo," Proceedings of the National Academy of Sciences of the United States of America, vol. 105, no. 7, pp. 2415-2420, 2008.

[24] Q. Bian, J. H. Huang, Q. Q. Liang et al., “The osteogenetic effect of astragaloside IV with centrifugating pressure on the OCT-1 cells," Pharmazie, vol. 66, no. 1, pp. 63-68, 2011.

[25] G. J. Dennis, B. T. Sherman, D. A. Hosack et al., "DAVID: database for annotation, visualization, and integrated discovery," Genome Biology, vol. 4, no. 5, article P3, 2003.

[26] B. Zhang, D. Schmoyer, S. Kirov, and J. Snoddy, "GOTree Machine (GOTM): a web-based platform for interpreting sets of interesting genes using Gene Ontology hierarchies," BMC Bioinformatics, vol. 5, article 16, 2004.

[27] S. J. H. Sui, J. R. Mortimer, D. J. Arenillas et al., "oPOSSUM: identification of over-represented transcription factor binding sites in co-expressed genes," Nucleic Acids Research, vol. 33, no. 10, pp. 3154-3164, 2005.

[28] G. U. Gangenahalli, P. Gupta, D. Saluja et al., "Stem cell fate specification: Role of master regulatory switch transcription factor PU.1 in differential hematopoiesis," Stem Cells and Development, vol. 14, no. 2, pp. 140-152, 2005.

[29] S. Carotta, A. Dakic, A. D’Amico et al., "The transcription factor PU.1 controls dendritic cell development and Flt3 cytokine receptor expression in a dose-dependent manner," Immunity, vol. 32 , no. 5, pp. 628-641, 2010.

[30] B. A. Reynolds and S. Weiss, "Generation of neurons and astrocytes from isolated cells of the adult mammalian central nervous system," Science, vol. 255, no. 5052, pp. 1707-1710, 1992.

[31] I. Singec, R. Knoth, R. P. Meyer et al., "Defining the actual sensitivity and specificity of the neurosphere assay in stem cell biology," Nature Methods, vol. 3, no. 10, pp. 801-806, 2006.

[32] S. Jessberger, G. D. Clemenson, and F. H. Gage, "Spontaneous fusion and nonclonal growth of adult neural stem cells," Stem Cells, vol. 25, no. 4, pp. 871-874, 2007.

[33] J. P. Saxe, H. Wu, T. K. Kelly et al., "A phenotypic small-molecule screen identifies an orphan ligand-receptor pair that regulates neural stem cell differentiation," Chemistry and Biology, vol. 14, no. 9, pp. 1019-1030, 2007.

[34] M. Nagao, M. Sugimori, and M. Nakafuku, "Cross talk between Notch and growth factor/cytokine signaling pathways in neural stem cells," Molecular and Cellular Biology, vol. 27, no. 11, pp. 3982-3994, 2007.

[35] Q. A. Liu and H. Shio, "Mitochondrial morphogenesis, dendrite development, and synapse formation in cerebellum require both Bcl-w and the glutamate receptor $\delta 2$," PLoS Genetics, vol. 4, no. 6, Article ID e1000097, 2008.

[36] B. Murphy, M. Dunleavy, S. Shinoda et al., "Bcl-w protects hippocampus during experimental status epilepticus," The American Journal of Pathology, vol. 171, no. 4, pp. 1258-1268, 2007.

[37] D. J. Veis, C. M. Sorenson, J. R. Shutter, and S. J. Korsmeyer, "Bcl2-deficient mice demonstrate fulminant lymphoid apoptosis, polycystic kidneys, and hypopigmented hair," Cell, vol. 75, no. 2, pp. 229-240, 1993.

[38] L. K. Ashman, “The biology of stem cell factor and its receptor C-kit," International Journal of Biochemistry and Cell Biology, vol. 31, no. 10, pp. 1037-1051, 1999.

[39] K. Jin, X. O. Mao, Y. Sun, L. Xie, and D. A. Greenberg, "Stem cell factor stimulates neurogenesis in vitro and in vivo," Journal of Clinical Investigation, vol. 110, no. 3, pp. 311-319, 2002.

[40] A. Erlandsson, J. Larsson, and K. Forsberg-Nilsson, "Stem cell factor is a chemoattractant and a survival factor for CNS stem cells," Experimental Cell Research, vol. 301, no. 2, pp. 201-210, 2004.

[41] Y. Sun, K. Jin, J. T. Childs, L. Xie, X. O. Mao, and D. A. Greenberg, "Vascular endothelial growth factor-B (VEGFB) stimulates neurogenesis: evidence from knockout mice and growth factor administration," Developmental Biology, vol. 289, no. 2, pp. 329-335, 2006.

[42] X. Zhu, S. Bidlingmaier, R. Hashizume, C. D. James, M. S. Berger, and B. Liu, "Identification of internalizing human single-chain antibodies targeting brain tumor sphere cells," Molecular Cancer Therapeutics, vol. 9, no. 7, pp. 2131-2141, 2010.

[43] A. M. Kenney and D. H. Rowitch, "Sonic hedgehog promotes G1 cyclin expression and sustained cell cycle progression in mammalian neuronal precursors," Molecular and Cellular Biology, vol. 20, no. 23, pp. 9055-9067, 2000.

[44] C. G. Feijóo, M. G. Oñate, L. A. Milla, and V. A. Palma, "Sonic hedgehog (Shh)-Gli signaling controls neural progenitor cell division in the developing tectum in zebrafish," European Journal of Neuroscience, vol. 33, no. 4, pp. 589-598, 2011.

[45] T. Hsu, M. Trojanowska, and D. K. Watson, "Ets proteins in biological control and cancer," Journal of Cellular Biochemistry, vol. 91, no. 5, pp. 896-903, 2004.

[46] V. I. Sementchenko and D. K. Watson, "Ets target genes: past, present and future," Oncogene, vol. 19, no. 55, pp. 6533-6548, 2000.

[47] I. G. Maroulakou and D. B. Bowe, "Expression and function of Ets transcription factors in mammalian development: a regulatory network," Oncogene, vol. 19, no. 55, pp. 6432-6442, 2000.

[48] S. Zhu, S. Barshow, J. Wildonger, L. Y. Jan, and Y. N. Jan, "Ets transcription factor Pointed promotes the generation of intermediate neural progenitors in Drosophila larval brains," Proceedings of the National Academy of Sciences of the United States of America, vol. 108, no. 51, pp. 20615-20620, 2011.

[49] A. L. Brass, A. Q. Zhu, and H. Singh, "Assembly requirements of PU.1-Pip (IRF-4) activator complexes: inhibiting function in vivo using fused dimers," EMBO Journal, vol. 18, no. 4, pp. 977991, 1999.

[50] R. P. DeKoter and H. Singh, "Regulation of B lymphocyte and macrophage development by graded expression of PU.1," Science, vol. 288, no. 5470, pp. 1439-1441, 2000.

[51] K. Lai, B. K. Kaspar, F. H. Gage, and D. V. Schaffer, "Sonic hedgehog regulates adult neural progenitor proliferation in vitro and in vivo," Nature Neuroscience, vol. 6, no. 1, pp. 21-27, 2003.

[52] R. Machold, S. Hayashi, M. Rutlin et al., "Sonic hedgehog is required for progenitor cell maintenance in telencephalic stem cell niches," Neuron, vol. 39, no. 6, pp. 937-950, 2003.

[53] R. J. Wechsler-Reya, "Analysis of gene expression in the normal and malignant cerebellum," Recent Progress in Hormone Research, vol. 58, pp. 227-248, 2003. 
[54] A. V. Molofsky, R. Pardal, T. Iwashita, I. K. Park, M. F. Clarke, and S. J. Morrison, "Bmi-1 dependence distinguishes neural stem cell self-renewal from progenitor proliferation," Nature, vol. 425, no. 6961, pp. 962-967, 2003.

[55] S. Oh, X. Huang, and C. Chiang, "Specific requirements of sonic hedgehog signaling during oligodendrocyte development," Developmental Dynamics, vol. 234, no. 3, pp. 489-496, 2005.

[56] S. Ahn and A. L. Joyner, "In vivo analysis of quiescent adult neural stem cells responding to Sonic hedgehog," Nature, vol. 437, no. 7060, pp. 894-897, 2005.

[57] C. Borday, P. Cabochette, K. Parain, and M. Perron, "Antagonistic cross-regulation between Wnt and Hedgehog signalling pathways controls post-embryonic retinal proliferation," Development, vol. 139, no. 19, pp. 3499-3509, 2012.

[58] R. K. Dave, T. Ellis, M. C. Toumpas et al., "Sonic hedgehog and notch signaling can cooperate to regulate neurogenic divisions of neocortical progenitors," PLoS ONE, vol. 6, no. 2, Article ID e14680, 2011. 


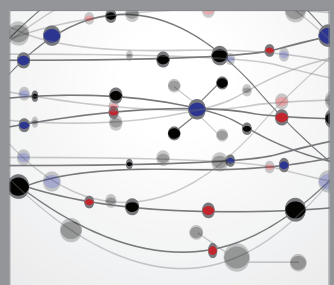

The Scientific World Journal
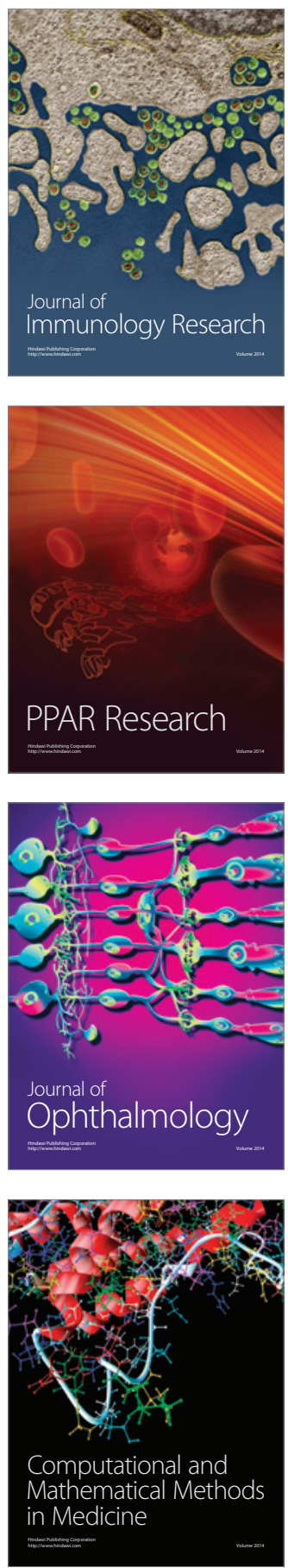

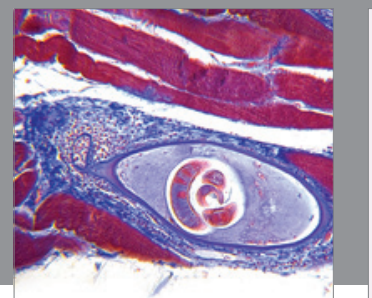

Gastroenterology

Research and Practice
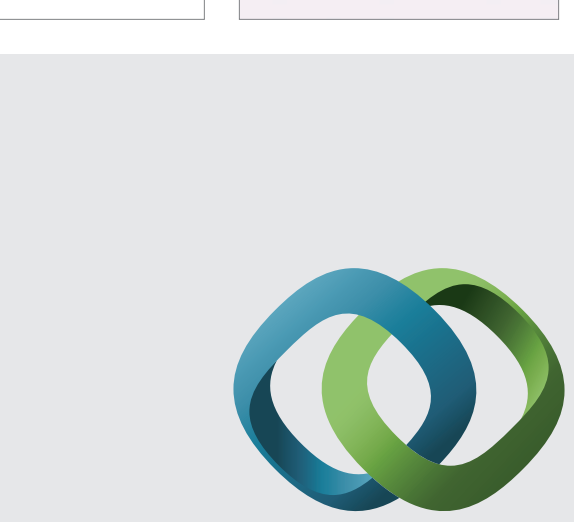

\section{Hindawi}

Submit your manuscripts at

http://www.hindawi.com
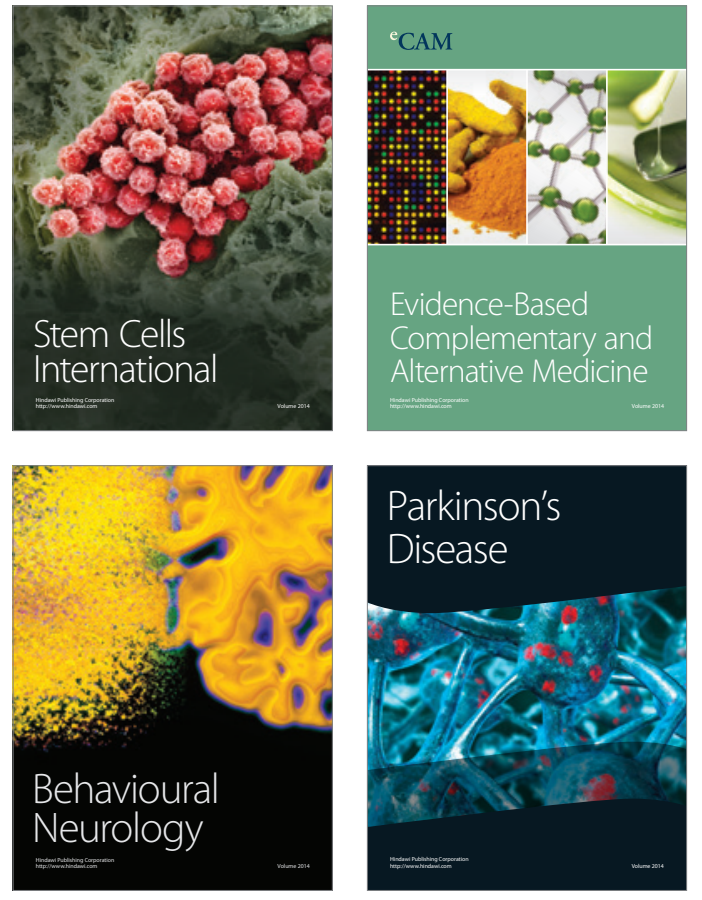
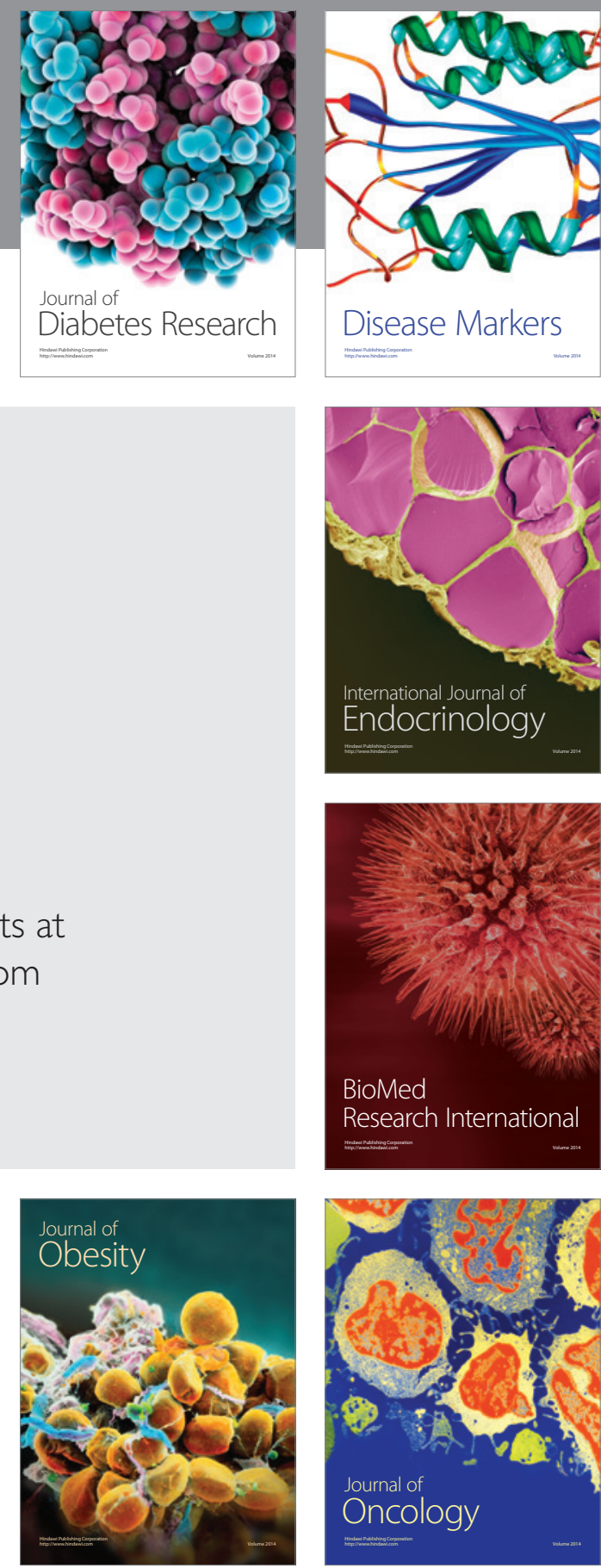

Disease Markers
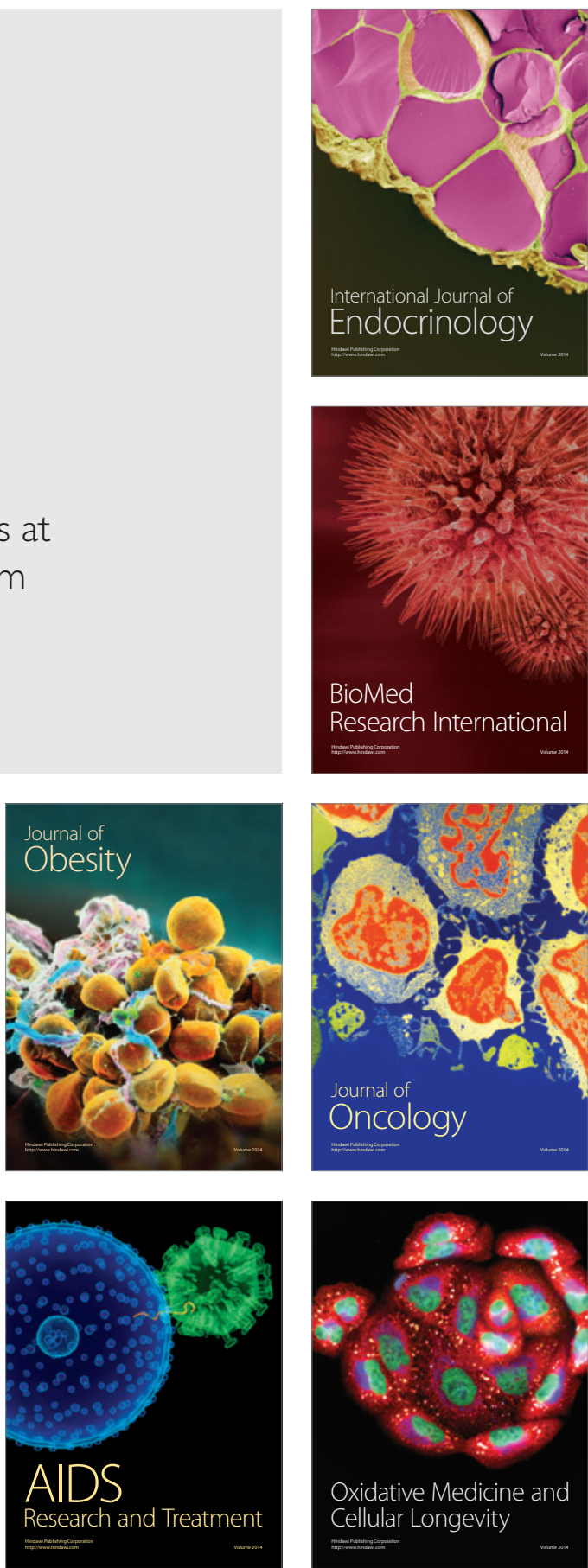